Осадчая Валерия Петровна

канд. филол. наук, доцент

Иванова Ольга Львовна старший преподаватель

Гетман Елизавета Иосифовна старший преподаватель

ФГБОУ ВО «Кубанский государственный университет физической культуры, спорта и туризма» Краснодар, Краснодарский край

DOI $10.31483 / r-75019$

\title{
CROSS-CULTURAL COMMUNICATION ISSUES OF EDUCATING BICULTURAL STUDENTS
}

Abstract: the article is devoted to the importance of incorporating of a foreign culture learning, acquiring cross-cultural communication and cultural awareness skills in a foreign language teaching. The authors point out that teaching culture in foreign language teaching context should include cultural knowledge, cultural values, cultural skills and behavior. The author also emphasize that attitudes to teaching culture in the process of foreign language teaching involve, on the one side, considering teaching culture as teaching the fifth language skill along with speaking, listening, reading and writing, implying teaching cultural sensitivity and cultural awareness or the behavior in certain cultural situations, and on the other side, regarding language as social practice being defined by culture in which culture becomes the core of language teaching with cultural awareness viewed as enabling language proficiency. Cultural awareness is the foundation of communication; it helps to understand cultural values, beliefs, and perceptions of the other culture. Training of both bilingual and bicultural students at higher educational institutions is of primary significance. 
Intercultural awareness presumes a number of skills, improving students' native culture and other cultures' awareness and understanding. The authors come to the conclusion that intercultural awareness skills imply overcoming misinterpretations and accepting differences.

Keywords: cross-cultural communication, cultural awareness, intercultural competence, verbal and body language, bilingual and bicultural students, global graduates.

Аннотация: статья посвящена важности включения изучения культуры изучаемого иностранного языка, приобретения навыков межкультурного общуения и культурной осведомленности в преподавание иностранного языка. Авторы подчеркивают, что обучение культуре в контексте преподавания иностранного языка должно включать культурные знания, культурные цуенности, культурные навыки и поведение. Авторы также отмечают, что отночение к преподаванию культуры в прочессе обучения иностранному языку подразумевает, с одной стороны, рассмотрение преподавания культуры как преподавания пятого языкового навыка вместе с говорением, аудированием, чтением и письмом, включая понятия культурной чувствительности и культурного сознания и поведения в определенных культурных ситуащиях, с другой стороны, рассмотрение языка как социчальной практики, определяемой культурой, при этом культура становится ядром преподавания языка, а культурная осведомленность рассматривается как возможность овладения языком в совершенстве. Культурная осведомленность является основой коммуникации, способствующей пониманию культурных цуенностей, убеждений и восприятию языка изучаемой культуры. Обучение студентов, в одинаковой степени владеющих двумя языками и двумя культурами в высшем учебном заведении, имеет первостепенное значение. Межкультурная осведомленность предполагает ряд навыков, улучшающих понимание учащчимися как родной культуры, так и других культур. Авторы приходят к выводу, что навыки межкультурной осведом- 
ленности подразумевают преодоление непонимания иной культуры и принятие различий между различньми культурами.

Ключевые слова: межкультурная коммуникация, культурная осведомленность, межкультурная компетенция, вербальное и невербальное общение, студенты, знающче два языка и две культуры, выпускники международного уровня.

In the modern multilingual and multicultural world people coming from different lingual and cultural backgrounds interact with each other more than ever, henceforth the issues of international and cross-cultural communication, cultural awareness and intercultural competence are of paramount importance. The purpose of the investigation is a survey of modern Internet publications on the topic with the aim of revealing of the latest data and incorporating the findings into the process of teaching the English language and culture at Kuban State University of Physical Education, Sports and Tourism.

Foreign language teaching implies acquiring knowledge about native speakers' culture. It is crucial to know the cultural context of the language taught and to incorporate culture into the process of teaching [5].

Intercultural communication is verbal and non-verbal interaction between people from different cultural backgrounds. Intercultural communication competence is the ability to understand both native and foreign language cultures, and use cultural awareness to communicate successfully with people from other cultures. It also means understanding how gestures and personal distance vary from culture to culture.

Cross-cultural ccommunication is the ability to form and improve associations with representatives of different cultures. It is based on the knowledge of other culture manners, values, decision-making practices and perceptions, and ways of oral, written, verbal and non-verbal communications. In order to understand each other people from different cultures should be able to distinguish between the norms and customs of interconnecting cultures. Researches of cross-cultural communication 
(Crystal, D., Harmer, G., Ter-Minasova, S. and others) examine how different cultures can be compared in terms of human behavior and address the worldwide concerns arising as an outcome of cultural differences and conflicts.

Understanding the problems of cross-cultural communication helps to appropriately adjust person's behavior to the norms of a different culture. There is a possibility that cultural differences may lead to communication problem and to be willing to be indulgent and tolerant [6].

As it is defined in Cambridge dictionary "Culture is the way of life, especially the general customs and beliefs, of a particular group of people at a particular time" [8]. Culture refers to hierarchies, religion, ways of behavior, notions of time, recognized symbols, spatial relations, daily life of individuals or group of people in the course of their life spans.

Culture covers commonly shared values, knowledge, attitudes, meanings traditions, experience, beliefs, and also cultural artifacts, arts or sports. Teaching culture in foreign language teaching context should include cultural knowledge, cultural values, cultural skills and behavior [4]. Use of English as a medium of interaction helps to develop perceptiveness, intercultural sensitivity and awareness. Thus, teaching of culture is considered as teaching the fifth language skill.

According to Barry Tomalin “...the international role of the English language and globalization are the two reasons to consider the teaching of cultural skills set as part of language teaching, the fifth language skill in addition to listening, speaking, reading and writing». He suggests rethinking teaching of culture and treat it as the 5th language skill, involving teaching cultural sensitivity and cultural awareness or the behavior in certain cultural situations» [3].

The fifth language skill is supposed to facilitate learning about other cultures and understanding them and to teach you techniques, helping to adapt your mind to other cultures' values and their unique qualities. It involves understanding how to use language to accept cultural difference, to be flexible and tolerant of things different. 
It is an attitudinal change that is expressed through language use. Cultural awareness is an interdisciplinary subject that draws on the resources of a variety of humanistic disciplines to profile the aptitudes and skills required to understand and work successfully in another culture.

Cultural awareness is another level of understanding culture. In the age of globalization cultural awareness is an overarching skill and a necessity. Cultural awareness is the foundation of communication and it involves the ability of standing back from native culture and becoming aware of cultural values, beliefs and perceptions of the culture of the language studied [7].

Cultural awareness assumes developing cultural sensitivity and cultural skills necessary for dealing with people belonging to other cultures. Cultural awareness implies willingness to learn and to seek new experiences as well as openness to life diversity. To develop cultural awareness it is essential to enjoy difference, to be alert of appropriate behavior in any situation, not to judge other people or their lifestyles in this multilingual and multicultural world. It is necessary to think what exactly the communicator means or what meaning interlocutors actually give to what is said. People evaluate and comment on situations in different ways. Sometimes, a situation that can be very sensitive in one culture may be expressed humorously in another one. Lack of cultural awareness may cause misunderstanding between communicating people. Misunderstanding happens when people suppose that their own rules are applicable to other cultures. For example, the Japanese consider it disrespectful to look directly in the partner's eyes. If a person does not have enough knowledge about the meaning of some behaviors in a foreign culture, one can get into ridiculous situation. The American preference for the first names is far from being universal, as is casual attire and allowing food in class. These informal preferences in the learning environment may cause discomfort in other cultures, where a more formal context is preferable. Individuals need to have cross-cultural awareness as well as linguistic, sociolinguistic and pragmatic competence. Cultural awareness allows individuals to ex- 
plore different worlds and to break stereotypical beliefs and prejudices and to have a broader look at the world.

Language is defined by culture. "If...language is seen as social practice, culture becomes the very core of language teaching. Cultural awareness must then be viewed as enabling language proficiency... Culture in language teaching is not an expendable fifth skill... to the teaching of speaking, listening, reading and writing" [2]. Language competence implies understanding forming its culture. While learning a foreign language it is essential to have both cultural and intercultural awareness, i.e., knowledge of the first language/first culture and the foreign language/foreign culture.

Thus two pronounced attitudes to teaching culture implied in the process of foreign language teaching can be can be singled out as the one of Barry Tomalin, considering teaching culture as teaching the fifth language skill and the other, regarding language as social practice being defined by culture, in which culture becomes the very core of language teaching, with cultural awareness being viewed as enabling language proficiency.

Intercultural awareness presumes a number of skills that help students to improve their native culture awareness and to interpret and understand other cultures. Intercultural awareness skills, constituting competence, involve overcoming misinterpretation and accepting difference.

Methodology for teaching cultures and developing intercultural communication includes foreign language culture researching in various media; giving presentations on the cultures considered; discussing experiencing another culture, either through travel and holidays or knowing someone from another culture.

Activities to promote bicultural awareness include:

- encouraging question and answer sessions about foreign language culture;

- comparing foreign language culture to students' native cultures;

- discussing popular television shows, slang, or other lifestyle characteristics. 
As students learn to compare native culture with foreign language culture, they can gain and improve appreciation of both cultures without minimizing or denigrating either of them. For those students who are interested in getting more information about other cultures teachers should encourage them to acquire cultural awareness and sensitivity concerning native and foreign cultures.

Global graduates are the new buzz phrase amongst graduate employers and higher education institutions meaning a generation of globally minded graduates that are culturally aware of the wider world in an increasingly competitive and internationalized marketplace. The Kuban State University of Physical Education, Sports and Tourism trains internationally competing top athletes, Physical Education and Sports Marketing specialists, that is why introduction of intercultural communication issues into the curriculum is vitally important. Issued by the University Teaching aids such as "Sport speaks English" and other combine language training and intercultural learning and cover topics like: "Communication styles", "First contact", "Conversations", "Invitation", "Punctuality and formality", "Stereotypes", "Talking about the weather", "Display of emotions" and so on [1]. Students are taught to think globally and to act interculturally when travelling around the world and taking part in international sport events.

In conclusion the following may be stated. The aim of the foreign language teaching is to educate bilingual students in their professional sphere and the additional purpose is to introduce them to the world of another culture, i. e., to educate bicultural students.

\section{Сиисок литературы}

1. Ярмолинец Л.Г. Иностранный язык. Sport speaks English: учебное пособие. - Краснодар: Изд-во КГУФКСТ, 2019.

2. Intercultural Learning 1. URL: https://www.teachingenglish.org.uk/article/ intercultural-learning-1 
3. Tomalin, B. Culture - the fifth language skill. URL: https://www. teachingenglish.org.uk/article/culture-fifth-language-skill

4. Tomalin, B. Making culture happen in the English classroom. URL: https://www.teachingenglish.org.uk/article/making-culture-happen-english-languageclassroom

5. The Acceptance and Recognition of Cultural Diversity in Foreign Language Teaching URL: https://www.researchgate.net/publication/49607040_The_Acceptance_ and_Recognition_of_Cultural_Diversity_in_Foreign_Language_Teaching

6. Intercultural communicative competence. URL: https://www.teachingenglish. org.uk/article/intercultural-communicative-competence

7. How to answer "Tell me about your cultural awareness?" URL: https://careersblog.warwick.ac.uk/2015/09/02/how-to-answer-tell-me-about-yourcultural-awareness/

8. Cambridge Dictionary. URL: https://dictionary.cambridge.org/ru 